\title{
CARBON DIOXIDE, A RELEASER FOR \\ DIGGING BEHAVIOR IN SOLENOPSIS GEMINATA (HYMENOPTERA: FORMICIDAE)*
}

\author{
By Walter Hangartner
}

\author{
Biological Laboratories, Harvard University
}

The behavior of ants digging through sand or clay in the direction of trapped nestmates has been described by Belt (1874) and Lafleur (1940). Wilson (1958) showed that in Pogonomyrmex badius (Latreille) this behavior pattern is released by a volatile substance originating from the mandibular glands. Later, McGurk et al. (1966) identified the responsible compound as 4-methyl-3-heptanone. At the same time, Blum and Warter (1966) isolated 2-heptanone from Conomyrma pyramica (Roger) and described its function as the releaser of alarm and digging behavior. Spangler (1968) reported that not only whole workers, but also amputated parts as well as larvae and pupae of Pogonomyrmex occidentalis (Cresson) attract workers of this species and release digging behavior. Forrest ( 1963 ) studied Lasius flavus nearcticus and four species of Acanthomyops and found that workers also dig to free ants of another species but attack them as soon as they are released.

During studies on a colony of Solenopsis geminata (Fabricius), I noticed that returning foragers started to remove a plug of cotton used to block the entrance of an artificial nest immediately after its mounting, even if the position of the entrance was rotated through $180^{\circ}$. During most of these actions, they used their mandibles to chew away small pieces of the obstacle. The purpose of the present paper is to report on the finding that this behavior is released by the carbon dioxide produced by the ants trapped inside the nest.

\section{Material and Method}

During the whole experimental period, the same colony of Solenopsis geminata was used. This colony consisted of several thousand workers, a queen, large piles of brood and a few hundreds of winged males and females which were all kept in a Wilson nest (Wilson, 1962a). To examine the digging behavior toward trapped nestmates, workers or other objects were trapped in the vial shown in Figure I. A hole $6 \mathrm{~mm}$ in diameter was punched through the top of the plastic

*Manuscript received by the editor March 16, 1969 
stopper and blocked again by gluing a piece of an index card (Oxford, 7I82 B) to it. The bottom of this stopper was perforated with a needle approximately 5o times, which allowed volatiles produced inside the vial to penetrate but at the same time prevented contact between the trapped ants and the cardboard. A capillary (i.d. I mm) was efficient enough to supply the trapped ants with the necessary oxygen, and a layer of moist cotton guaranteed the essential humidity. The control bottle was prepared in the same way but contained only moist cotton. The test- and the control-tube were presented simul-

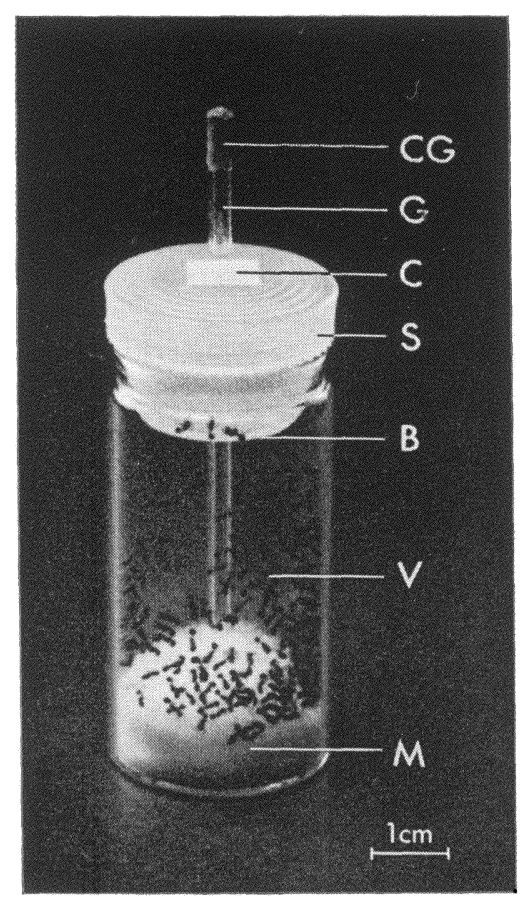

Figure 1. Arrangement used to measure the digging activity of Solenopsis geminata released by trapped nestmates.

V Glass vial

S Plastic-Stopper

C Cardboard blocking a hole $(6 \mathrm{~mm})$ punched through the top of the stopper

B Perforated bottom of the stopper

G Glass capillary (gas exchange)

CG Copper gauze

M Moist cotton. 
taneously on top of the nest and left there for 20-22 hours. Because the cardboard covering the hole on top of the stopper was the only material the ants could remove in attempting to reach the trapped workers, all their digging activity was directed towards these areas. After each test, the pieces of cardboard were therefore removed and the "damage" done to them by the digging ants examined. The following scoring system was used to quantify the findings:

$n$ : No visible chewing marks on the surface of the cardboard

I : Superficial chewing marks

2 : Heavy chewing marks

3 : Only a transparent film of cardboard remains at the site of digging

4 : The diameter of the hole dug is $<\mathrm{I} \mathrm{mm}$

5 : The diameter of the hole dug is $>\mathrm{I} \mathrm{mm}$

6 : The diameter of the hole dug is $>2 \mathrm{~mm}$

7 : The diameter of the hole dug is $>3 \mathrm{~mm}$

If the ants worked on more than one place, the different scores were added. Each test was repeated at least five times.

\section{RESULTS}

Fifteen to thirty minutes after the bottles were placed on top of the nest, some workers could be observed palpating the surface of the cardboard-seal on the test-tube with their antennae. Others just rested on this place for a few minutes, their antennae slightly raised. Suddenly, a single ant started to work on the cardboard with its mandibles, rather hesitating at first, but gradually with more vigor. When one individual became involved in such activity, it soon was joined by at least another ant, and occasionally I noticed up to ten workers chewing at the same spot. The digging ants sometimes were replaced by other nestmates after various times, or they continued working until a hole was punctured. Very often, however, they abandoned this behavior before an opening was created, leaving only chewing-marks of different intensities.

Table I. Result of the digging behavior released by trapped workers, females, males or brood (larvae and pupae approx. I:I). The mean activity is based on eight repetitions.

Trapped individuals
200 workers
I5 winged females
20 winged males
200 larvae \& pupae
Control

Average digging

response
5.6
5.0
4.6
4.6
0.4


The first experiment showed that the behavior pattern just described can be released by trapped workers, females, males, and even brood (Table I). The positive result obtained with brood indicates that the "rescue" activity can be initiated by something more than stridulation of the trapped individuals, the mechanism in leaf-cutting ants (Markl, 1967). Stridulation can also be ruled out by trapping dead ants which have been killed by chilling just before the experiment. In series $A$, the dead workers were presented intact, whereas in series $B$, they were homogenized, transferred to a small piece of cotton and trapped in this way. In both cases the small pieces of cardboard were replaced after 20 hours and the experiment stopped after 44 hours.

Figure 2 shows that the homogenized ants release a stronger digging activity than the intact ones and that this activity increases with

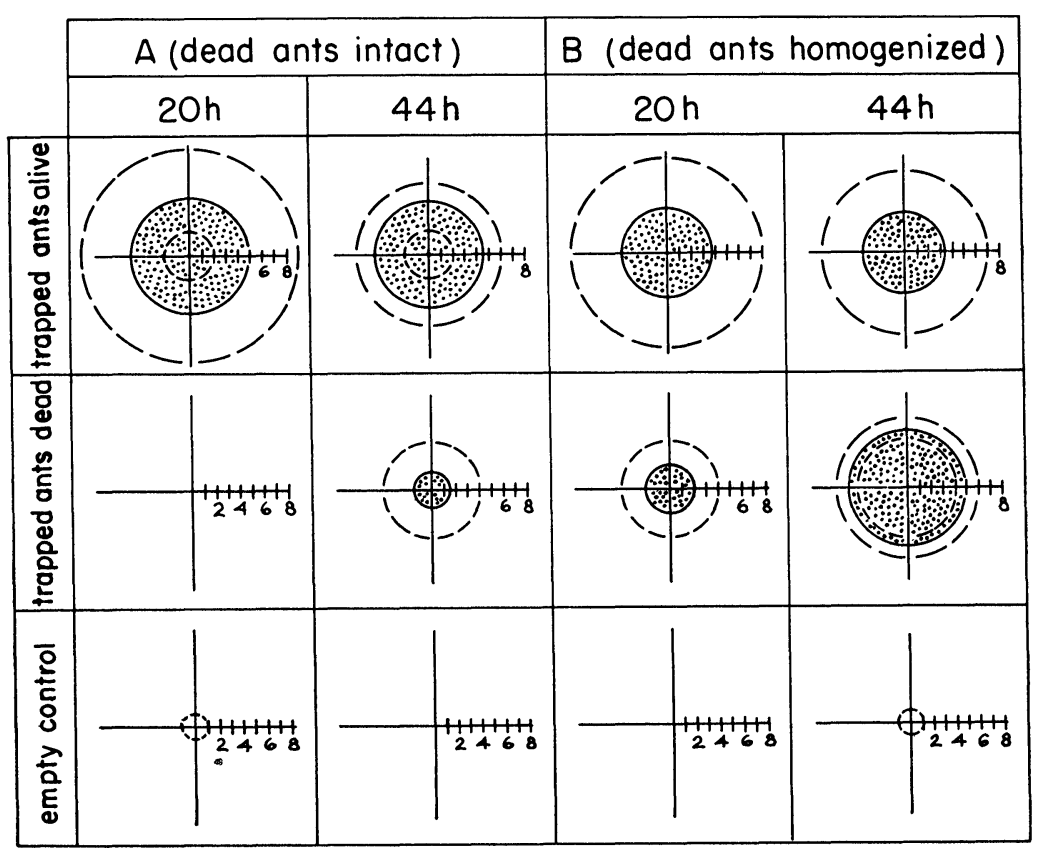

Figure 2. Comparison of the digging activity released by living and dead ants recorded after 20 and $44 \mathrm{~h}$, respectively. Series A: Dead workers intact, Series B: Dead workers homogenized. The radius of the stippled areas represents the average digging response and the radius of the dashed circles indicates the range of the 10 experiments performed. 
increasing decomposition time of the dead ants. There are at least 2 possible explanations to this phenomena:

I. The chemical releaser for digging behavior is produced somewhere inside the ant's body and, therefore, requires some time to diffuse to the surface of a dead worker to become active. This diffusion time is reduced if the workers are homogenized.

2. The responsible pheromone is a product of decomposition. Decomposition starts slower in intact ants, because an uninjured integument represents a certain barrier for external factors which induce or accelerate the decomposition process.

The first explanation is weakened by the fact that I did not succeed in localizing a gland responsible for the production of a pheromone. The second explanation, on the other hand, is slightly supported by the following finding: In Solenopsis saevissima, products of decomposition accumulate in the body of dead workers no sooner than 24 hours (Wilson et al. 1958). That is about the period during which I could not observe any digging behavior toward trapped geminata-corpses (see Fig. 2). Looking therefore for volatile products of decomposition that are also emitted by the living ants and brood, it seemed reasonable to suspect a substance such as carbon dioxide.

To obtain initial information about the value of this prediction, a small plastic container holding $0.5 \mathrm{ml}$ of $\mathrm{I} \mathrm{M} \mathrm{NaOH}$ was introduced into the space between top and bottom of the stopper (cf. Fig. I). A second stopper was prepared in the same way, but the container was filled only with $0.5 \mathrm{ml}$ distilled water. Each stopper was used to seal a vial containing I 50 workers. A third bottle did not contain ants and its container was empty. Table 2 shows that the presence of $\mathrm{NaOH}-$ a powerful absorbent for $\mathrm{CO}_{2}$ - actually influences the digging behavior negatively. It reduces the average digging response to almost the same low level as found in the control.

Table 2. Effect of $\mathrm{NaOH}$ on the digging behavior of ants toward trapped nestmates. Number of repetitions: Io.

\begin{tabular}{|c|c|c|c|}
\hline $\begin{array}{l}\text { Number of } \\
\text { trapped ants }\end{array}$ & $\begin{array}{l}\text { Contents of } \\
\text { inserted container }\end{array}$ & $\begin{array}{l}\text { Average } \\
\text { digging } \\
\text { response }\end{array}$ & Range \\
\hline I 50 & $0.5 \mathrm{ml} \mathrm{H}_{2} \mathrm{O}$ dist. & 3.6 & $I-6$ \\
\hline I 50 & $0.5 \mathrm{ml} \mathrm{I} \mathrm{M} \mathrm{NaOH}$ & 0.5 & $0-2$ \\
\hline o (control) & empty & $0 . \mathrm{I}$ & O-I \\
\hline
\end{tabular}


This result supports the $\mathrm{CO}_{2}$-hypothesis, but is not absolutely conclusive, because Sodium hydroxide could absorb other volatiles beside $\mathrm{CO}_{2}$. In an attempt to get a more direct proof, I performed the following experiment: 5 bottles were prepared in the way shown in Figure I except that they did not contain any ants. They were then connected with $U$-shaped pieces of glass tubing (i.d. $1.5 \mathrm{~mm}$ ) as demonstrated on top of Figure 3. After the whole system has been placed on a Wilson nest, a slow $\mathrm{CO}_{2}$-stream $\left(3.5 \mathrm{~cm}^{3} / \mathrm{min}\right)$ was pressed into one end of the tubing. Due to loss of $\mathrm{CO}_{2}$ through the cardboard and perhaps tiny leaks in the stoppers, only traces of this gas left the opening at the other end. I, thereby, got a more or less continuous gradient from a relatively high $\mathrm{CO}_{2}$-concentration (vial I) to a relatively low concentration (vial 5). Simultaneously I employed a second system of the same design, but compressed air was used instead of $\mathrm{CO}_{2}$ (control). In 20 hour-intervals, the cardboard on each stopper was replaced by a new one. The results of five repetitions can be taken from Figure 3 (bottom).

It is evident that a relatively low concentration of $\mathrm{CO}_{2}$ is able to release the same behavior pattern as do trapped workers. However, the efficiency of this releaser decreases with increasing concentration. It might be of interest to notice that ants which punctured the cardboard of vial 3 died or were at least anesthetized after penetration into the interior of the stopper, whereas this effect could not
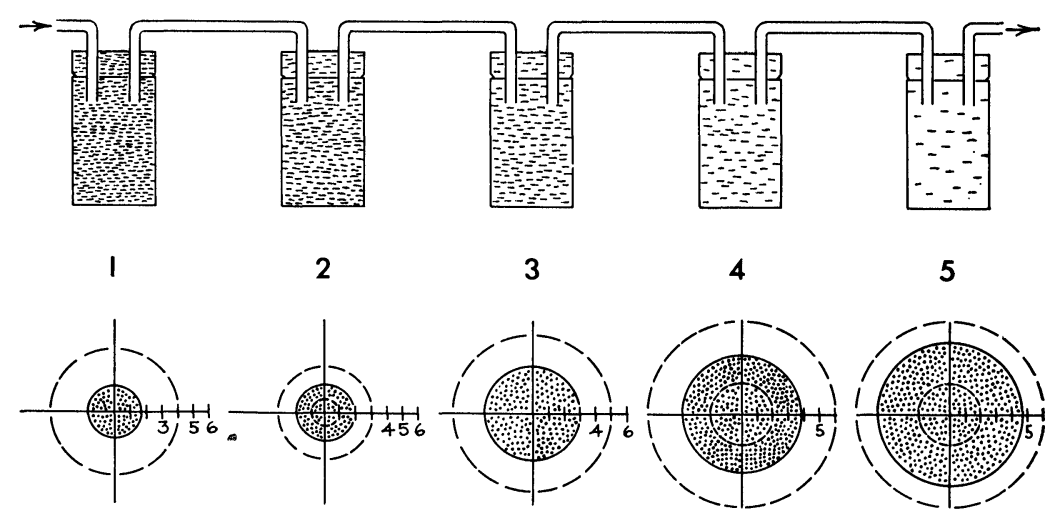

Figure 3. Arrangement (top) and results (bottom) of the experiment to test the effectiveness of $\mathrm{CO}_{2}$ as a releaser for digging behavior. The density of the dashes represents the relative concentration of carbon dioxide inside the vials, and the arrows show the direction of the gas flow. The radius of the stippled circle areas represents the average digging response and the dashed circles indicate the range of five experiments. 
be observed in either vial 4 or 5. This means that only concentrations of carbon dioxide which are harmless for these animals act as a highly efficient digging stimulus. No positive result could be registered in the control experiment, which indicates that pure air is completely inactive as a releaser of digging behavior.

If the $\mathrm{CO}_{2}$ produced by trapped workers of Solenopsis geminata is the only substance responsible for the release of the described behavior, members of this species should also dig toward locked up ants of other species. I therefore trapped I 50 workers of Solenopsis geminata, I 50 workers of the closely related fire ant Solenopsis saevissima (Myrmicinae) and 30 workers of Acanthomyops interjectus, belonging to a different subfamily (Formicinae). The control-vial was empty. The 4 tubes were presented to the geminata-colony simultaneously, and the results are shown in Table 3.

All three species released digging behavior that is definitely above the control. The relatively small activity toward Acanthomyops interjectus is probably due to the fact that Acanthomyops species produce volatiles which have a strong repellant effect against members of other ant species (Regnier and Wilson, I968 and pers. commun.).

Table 3. Results of the digging behavior of Solenopsis geminata released by trapped workers of Solenopsis geminata, Solenopsis saevissima and Acanthomyops interjectus. (Mean and range of ten repetitions).

\begin{tabular}{lcc} 
Trapped species & $\begin{array}{c}\text { Average } \\
\text { digging } \\
\text { response }\end{array}$ & Range \\
\hline S. geminata & $4 . \mathrm{I}$ & $\mathrm{I}-6$ \\
S. saevissima & $5 . \mathrm{O}$ & O-IO \\
A. interjectus & 2.8 & O-6 \\
Control & O.I & O-I
\end{tabular}

\section{Discussion}

$\mathrm{CO}_{2}$ is well known to attract the blood-feeding sexes of haematophagou's arthropods (Reeves, Wiesinger, Carcia, Fallis and Smith, Nelson, Wilson et al., Kato et al., De Foliart and Morris, Thompson, in Anderson and Olkowski, 1968). Lacher (1964) found receptor cells on the antennae of workers and males of the honey bee which respond specifically to $\mathrm{CO}_{2}$. Lacher (1964) and Boeck et al. ( 1965 ) speculated that this $\mathrm{CO}_{2}$-response may serve the colony in controlling the concentration of carbon dioxide in the interior of the hive. Such a function, however, remains without proof. In the 
myrmecine ant Solenopsis saevissima, Wilson (1962b) demonstrated that carbon dioxide acts as a weak attractant that finally leads to settling. Because the same behavior could be observed during these studies on Solenopsis geminata, I consider the digging activity released by $\mathrm{CO}_{2}$ as a by-product of attraction enabling the ants to get closer to the source of the stimulus. This interpretation is supported by the observation that if there is no hindrance between the workers and the source of $\mathrm{CO}_{2}$, the ants are merely attracted to the place where the concentration is most convenient; no digging behavior can be observed in such a case.

The results presented in this paper offer a possible explanation to all the observations of digging behavior toward trapped ants as cited in the introduction. This of course does not mean that the same mechanism works in all ant species. The finding that single individuals of Pogonomyrmex badius or even parts of a worker release digging behavior (Spangler, I968) indicates that this species is extremely sensitive to $\mathrm{CO}_{2}$, or it could also be that other chemical stimuli are involved. The whole surface of the ant's body as well as larvae and pupae could be contaminated by 4-methyl-3-heptanone, the compound identified as releaser for alarm and digging behavior (McGurk et al., 1966).

Because $\mathrm{CO}_{2}$-concentrations up to $\mathrm{I}-2 \%$ were demonstrated in the interior of ant nests (Poitier and Duval, 1929; Raffy, 1929), this simple molecule could accomplish the following functions in a Solenopsis geminata colony:

I. It acts as a pheromone to control settling inside the nest (Wilson, $1962 b$ ).

2. It diffuses through the nest entrance and serves as an orientation aid, at least in the near vicinity of the nest. [Wilson (1962b) concluded that fire ant workers are able to move up $\mathrm{CO}_{2}$ gradients.]

3. It acts as a "rescue"-pheromone in case groups of ants are trapped following a major cave-in.

4. The $\mathrm{CO}_{2}$ produced by large piles of brood attracts the workers necessary to take care of the larvae and pupae.

Although there may exist other or stronger stimuli which control these behavior patterns, $\mathrm{CO}_{2}$ at least plays an important supportive role.

\section{SUMMMARY}

Workers of Solenopsis geminata are attracted to low concentrations of $\mathrm{CO}_{2}$ and try to dig through all obstacles in order to get close enough to the source of this chemical stimulus. 


\section{ACKNOWLEDGeMENTS}

Thanks are due to Dr. E. O. Wilson and Mr. J. M. Reichson for their reading of the manuscript. The author is also grateful to Miss N. K. Lind, who offered many useful suggestions.

This work was supported by Grant No. GB7734 of the U. S. National Science Foundation (Dr. E. O. Wilson sponsor) and a grant from the Swiss National Science Foundation.

Anderson, J. R. AND W. Olkowski

\section{Literature Cited}

1968. Carbon dioxide as an attractant for host-seeking Cephenemyia females (Diptera: Oestridae). Nature 220: 190-191.

BELT, T.

1874. The naturalist in Nicaragua. Murray, London, $403 \mathrm{pp}$.

BLUM, M. S. AND S. L. W ARTER

1966. Chemical releasers of social behavior. VII. The isolation of 2-heptanone from Conomyrma pyramica (Hymenoptera: Formicidae: Dolichoderinae) and its modus operandi as a releaser of alarm and digging behavior. Ann. Ent. Soc. Amer. 59: 774-779.

Boeckh, J., K. E. Kaissling and D. Schneider

1965. Insect olfactory receptors. Cold Spring Harbor Symposia on quantitative Biology 30: 263-280.

ForRest, H. F.

1963. Three problems in invertebrate behavior. II. The digging out of trapped or buried ants by other workers. Ph.D. Thesis, Rutgers, 91-219.

LACHER, V.

1964. Elektrophysiologische Untersuchungen an einzelnen Rezeptoren für Geruch, Kohlendioxyd, Luftfeuchtigkeit and Temperatur auf den Antennen der Arbeitsbiene und der Drohne (Apis mellifica

LAFLeUR, L. J.

L.). $Z$. vergl. Physiol. 48: 587-623.

1940. Helpfulness in ants. J. comp. Psychol. $30:$ 23-29.

MARKL, H.

1967. Die Verständigung durch Stridulationssignale bei Blattschneiderameisen. I. Die biologische Bedeutung der Stridulation. $Z$. vergl. Physiol. 57 : 299-330.

McGurk, D. J., J. Frost, E. J. Eisenbraun, K. Vick, W. A. Drew and J. Young

1966. Volatile compounds in ants: identification of 4-methyl-3-heptanone from Pogonomyrmex ants. J. Insect Physiol. 12: 1435-1441.

Portier, P. and M. Duval

1929. Recherches sur la teneur en gaz carbonique de l'atmosphère interne des fourmilières. C. R. Soc. Biol. (Paris) 3 : 906-908.

RAFFY, A.

1929. L'atmosphère interne des fourmilières contient-elle de l'oxyde de carbone? C. R. Soc. Biol. (Paris) 3: 908-909.

REgnier, F. E. AND E. O. Wilson

1968. The alarm-defense system of the ant Acanthomyops claviger. J. Insect Physiol. 14: 955-970. 
SPANGLER, H. G.

1968. Stimuli releasing digging behavior in the western harvester ant (Hymenoptera: Formicidae). J. Kans. Ent. Soc. 41: 318-323.

WILSON, E. O.

1958. A chemical releaser of alarm and digging behavior in the ant Pogonomyrmex badius (Latreille). Psyche 65: 41-51.

1962a. Chemical communication among workers of the fire ant Solenopsis saevissima (Fr. Smith). 1. The organisation of mass-foraging. Animal Behaviour 10: 134-147.

1962b. Chemical communication among workers of the fire ant Solenopsis saevissima (Fr. Smith). 3. The experimental induction of social responses. Animal Behaviour 10: 159-164.

Wilson, E. O., N. I. Durlach and L. M. Roth

1958. Chemical releasers of necrophoric behavior in ants. Psyche 65: 108-114. 

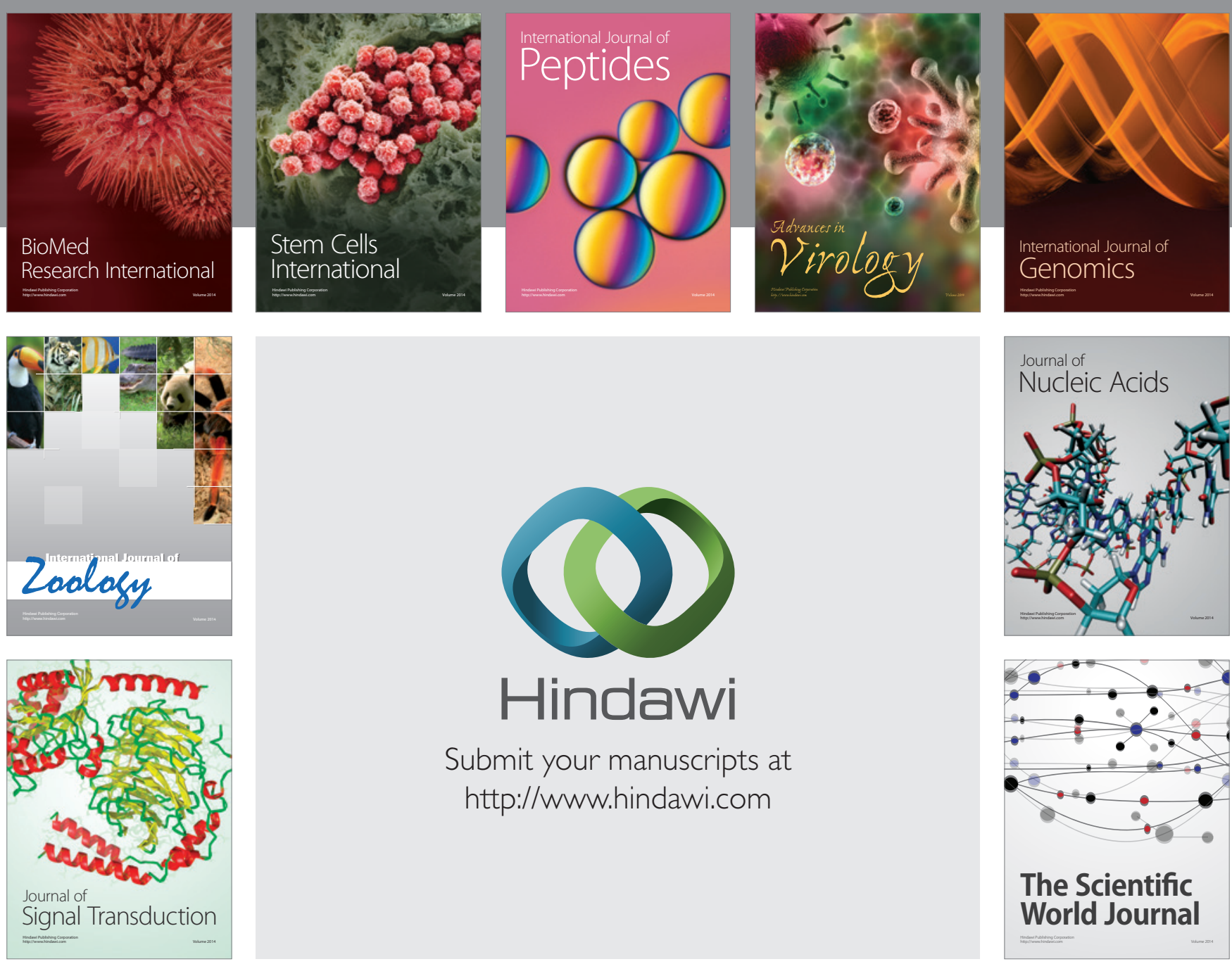

Submit your manuscripts at

http://www.hindawi.com
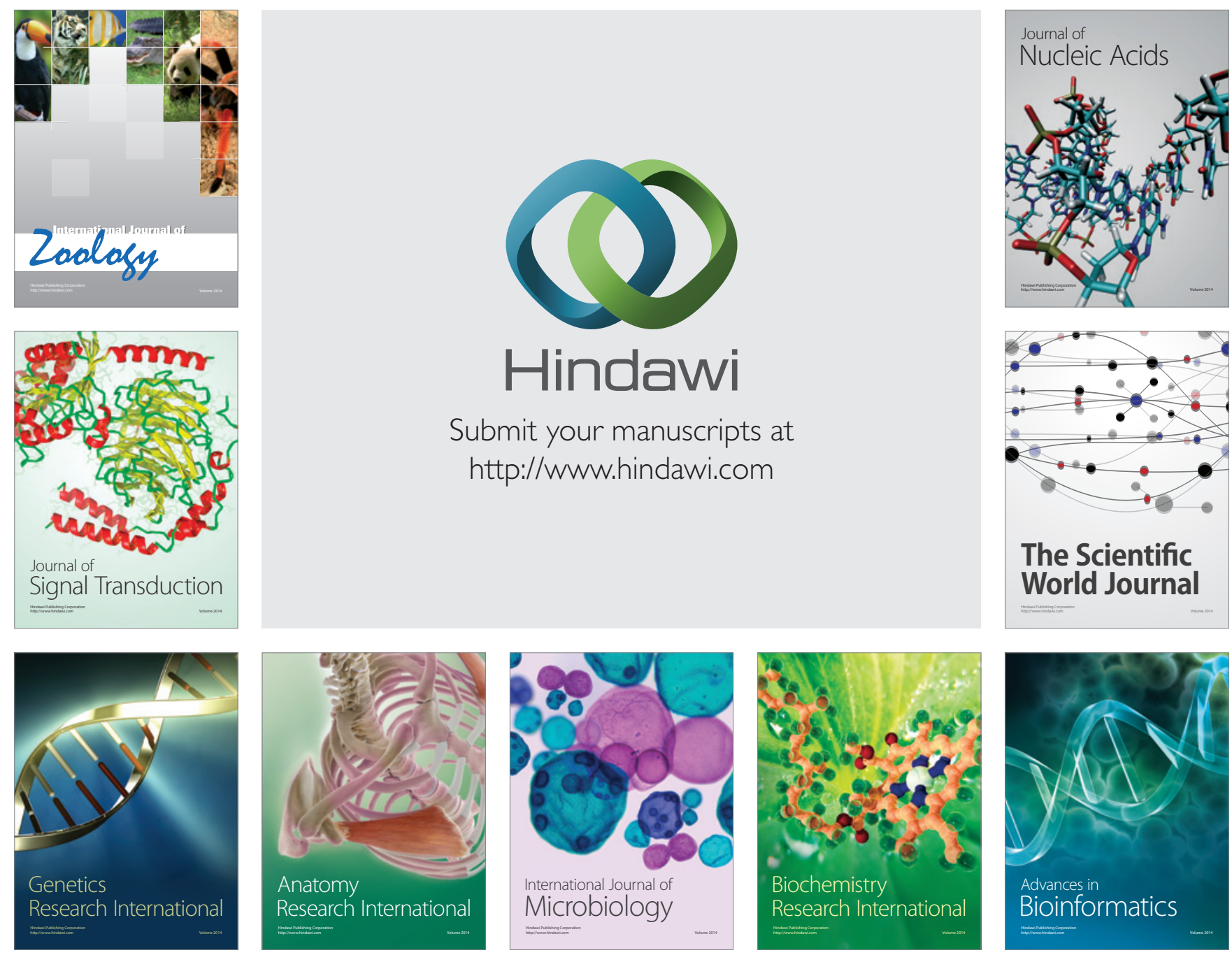

The Scientific World Journal
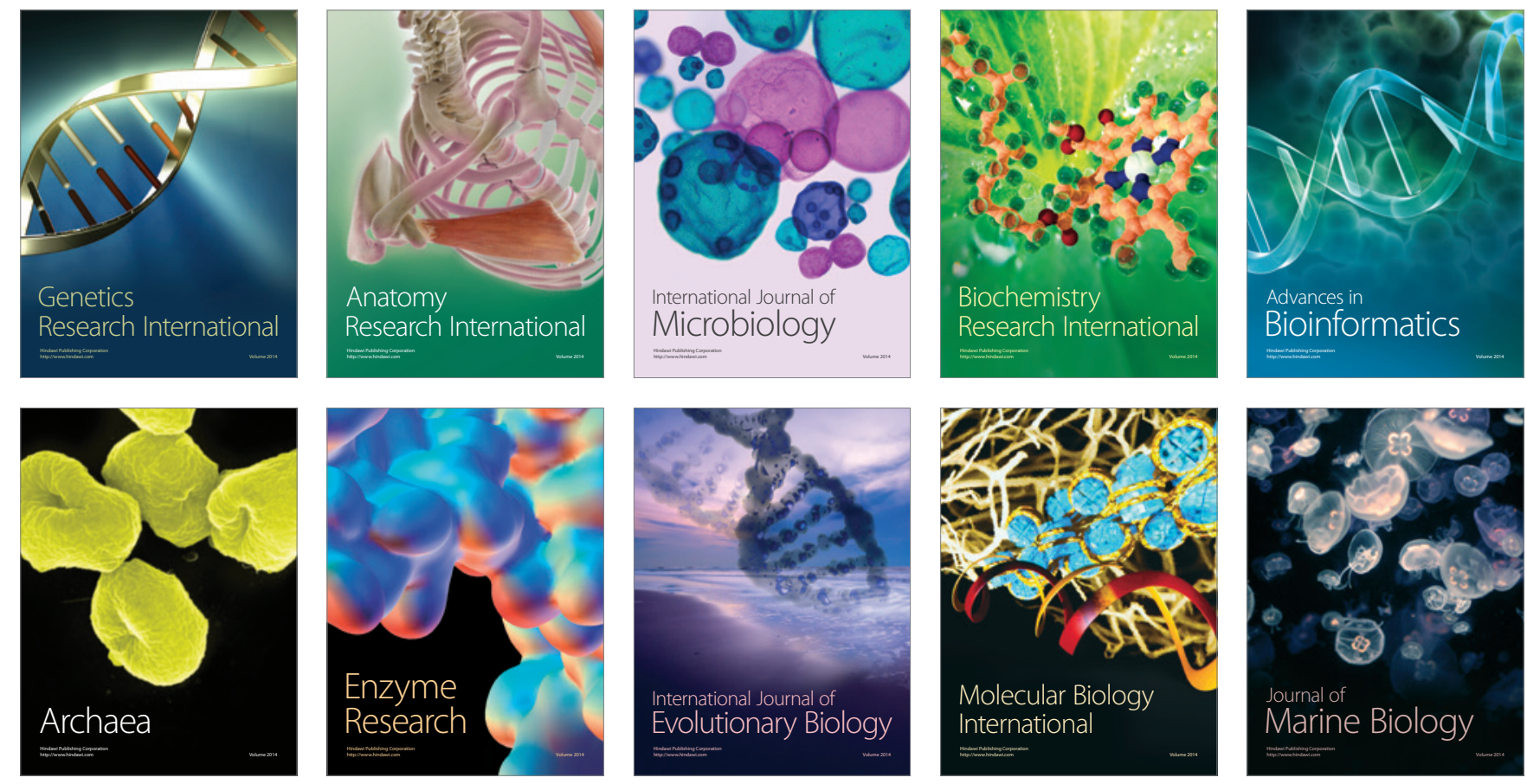